\title{
A DIMENSÃO PEDAGÓGICA NA DRAMATURGIA DE PEPETELA
}

\section{THE PEDAGOGICAL DIMENSION IN PEPETELA'S DRAMATURGY}

Márcia Regina Rodrigues ${ }^{1}$

\section{RESUMO}

Nesta abordagem da dramaturgia de Pepetela, produzida no contexto sociopolítico de Angola no período pós-independência, tratamos do caráter didático e épico que aproxima as suas peças da proposta teatral de Brecht. O autor angolano parte do ostensivamente didático em $A$ corda (1978) para uma concretização mais efetiva dos pressupostos épico-brechtianos em $A$ revolta da casa dos ídolos (1980), sem descartar a dimensão pedagógica em nenhuma de suas peças.

PALAVRAS-CHAVE: dramaturgia de Pepetela; peça didática; teatro épico brechtiano.

\section{ABSTRACT}

In this approach to Pepetela's dramaturgy, produced in the social-political context of Angola in the post-independence period, we address its didactic and epic character that resembles Brecht's theatrical proposition. The Angolan author goes from the professedly didactic play The rope (A corda, 1978) to a more effective implementation of the epic Brechtian assumptions in The revolt in the house of the idols (A revolta da casa dos idolos, 1980), without discarding the pedagogical dimension in any of his plays.

KEYWORDS: Pepetela's dramaturgy; didactic play; Brecht's epic theatre. 


\section{O BREVE PERCURSO DRAMATÚRGICO DE PEPETELA}

NANGA: [...] Vou fechar os olhos para não ver? Vou fechar os ouvidos para não ouvir? [...] A realidade força-me a pensar e a aprender (PEPETELA, 1980, p. 59-60).

A incursão do romancista angolano Pepetela - como se sabe, nome literário de Artur Carlos Mauricio Pestana dos Santos - na dramaturgia se dá com a publicação de duas peças: A corda, escrita em 1976, publicada em 1978, e A revolta da casa dos ídolos, escrita em 1979, publicada em $1980^{2}$. A corda foi levada à cena, em 1980, pelo Grupo de Instrutores de Teatro (GIT), com direção do cubano Ignazio Gutierrez; em 1984/1985, a peça foi representada no Lubango, província de Huíla, por alunos de 14 a 18 anos, do Instituto Médio Friedrich Engels, dirigidos pela professora Anabela Arede. Já A revolta da casa dos ídolos foi encenada em maio de 1988 pelo grupo Elinga-Teatro e representou Angola no II Encontro de Teatro Africano na Itália, em setembro daquele mesmo ano.

O entrecho dessas duas peças insere-se no contexto sociopolítico do período pós-independência (1975) e, de forma direta ou alegórica, trata das questões que obstaram a concretização do sonho da unidade nacional angolana, como a desmedida luta pelo poder; o oportunismo das lideranças políticas, guiado pela corrupção; a tensão entre tradição e renovação (HILDEBRANDO, 2009); enfim, as relações conflituosas entre dominadores e dominados, exploradores e explorados. Lembramos que Pepetela não só esteve envolvido no processo de libertação de Angola, como também participou do governo após a independência do país, tendo sido vice-ministro da Educação até o ano de 1982 e presidente da Comissão Nacional para a Unesco (CHAVES \& MACÊDO, 2009).

Quanto à composição dramatúrgica, consideramos nessas peças os elementos cênicos que as aproximam das características do teatro didático e do teatro épico desenvolvido e proposto por Bertolt Brecht, cujo objetivo principal seria o de despertar o senso crítico do espectador e levá-lo à conscientização dos problemas sociais e políticos de seu tempo.

Se em sua primeira peça, $A$ corda, Pepetela insiste no caráter didático da fábula ao apresentar o jogo do cabo de guerra entre revolucionários e imperialistas, em A revolta da casa dos ídolos, o autor recria no palco um episódio histórico do século XVI - a manifestação popular, ocorrida em 1514, contra a ordem dos portugueses de proibição e apreensão dos amuletos religiosos africanos - e elabora uma dramaturgia mais bem estruturada que favorece o surgimento do efeito de distanciamento (Verfremdungse$f f e k t)^{3}$, principal característica do teatro épico brechtiano. A forma alegórica do tratamento dramatúrgico de $A$ revolta da casa dos ídolos também a aproxima das peças dos autores portugueses que primeiro se apropriaram da lição de Brecht na dramaturgia produzida nos anos de 1960 - diga-se de passagem, momento em que Pepetela se encontrava em Portugal ${ }^{4}$. Estamos 
nos referindo às peças $O$ render dos heróis (1960), de José Cardoso Pires, e Felizmente, há luar! (1961), de Luís de Sttau Monteiro, que, fazendo uso da matéria histórica na construção da fábula ${ }^{5}$, objetivavam provocar no público a reflexão sobre as relações de poder, o autoritarismo e, consequentemente, sobre o regime ditatorial português.

Considerando-se a relação das peças de Pepetela com a proposta de teatro de Brecht, podemos para já afirmar que a obra do autor angolano, num percurso semelhante ao do próprio Brecht, parte do propósito meramente didático, trabalhado ostensivamente na primeira peça, para o desenvolvimento de uma dramaturgia mais épica-brechtiana, sendo que em nenhuma dessas peças é descartada a dimensão pedagógica.

Em A corda, é representado o conhecido jogo do cabo de guerra: cada equipe - de um lado a dos imperialistas e de outro a dos combatentes - deverá puxar uma das duas pontas da corda; aquela que conseguir levar o lenço vermelho, amarrado no meio da corda, até a tabuleta de número três será a vencedora e ficará com Angola: "O país, as suas riquezas, vocês todos, nós todos, pertenceremos ao vencedor" (PEPETELA, 1980, p. 8), diz Likishi ${ }^{6}$, personagem que tem a função de juiz do combate. Na equipe dos imperialistas, vemos transportados para o palco líderes e integrantes dos movimentos de libertação de Angola que na vida real surgiram na década de 1960: Savimbi (fundador e líder da União Nacional para a Independência Total de Angola, a UNITA), Daniel Chipenda (integrante do Movimento para Libertação de Angola, MPLA, que após liderar as Forças Armadas para a Libertação de Angola - FAPLAs - deixa de fazer parte do movimento) e Holden Roberto (da Frente Nacional de Libertação de Angola FNLA); essas três personagens são apoiadas pelo Americano e pelo Racista sul-africano. Cada integrante da equipe de combatentes se apresenta como "Povo Angolano", são cinco ao todo e cada um é proveniente de uma região do país; assim, o $1^{\circ}$ combatente é kimbundo de Luanda (reduto do MPLA); o $2^{\circ}$, umbundo de Huambo (a maioria dos integrantes da UNITA era umbundo); o $3^{\circ}$ é o tchokuê de Saurimo (Lunda Sul - rica em diamantes); o $4^{\circ}$ é mestiço, de Cabinda, e finalmente o $5^{\circ}$ é branco, de Lubango (sul de Angola, maior concentração de brancos do país). Já nessa caracterização das personagens fica evidente a razão coletiva do grupo de combatentes e o caráter individualista dos imperialistas, o que não significa que na equipe dos combatentes não haja certa tensão, muito embora sendo essa provocada pelos integrantes do grupo opositor.

As cenas mostram, de um lado, os bastidores do poder com as tramoias dos imperialistas, que, focados na exploração das riquezas de Angola (diamantes e petróleo), agem em prol de seus interesses pessoais; e, de outro lado, as dificuldades de organização da equipe de combatentes. Os dois principais problemas dos combatentes, a rivalidade entre tribos angolanas (tribalismo) e o racismo, são, na verdade, incitados pelos imperialistas, que a todo custo tentam enfraquecer o grupo de revolucionários: 
AMERICANO: (passando o braço pelo ombro) No campo deles há um combatente que é do Huambo. Vai falar com ele, dá a entender que ele está feito contigo. Para os dividir, percebes?

SAVIMBI: Dividir? Dividir é comigo. Eu divido tudo, o Povo, o País, as bananas, a mandioca, quatro a dividir por dois dá dois. Multiplicar ou somar já não sei, mas dividir... Aprendi na Suíça, quando tirei o curso de doutor de seis meses.

(PEPETELA, 1980, p. 23)

Na cena XI, os combatentes finalmente compreendem que precisam lutar juntos, e na cena XII, última da peça, mostram-se finalmente unidos, fazendo tremer os imperialistas que largam a corda e saem de cena fugindo. A peça termina com a vitória do "Povo Angolano"; os combatentes e Likishi comemoram: "(de braços erguidos dançando) Um só povo, uma só nação!” (PEPETELA, 1980, p. 49).

As referências ao contexto político da sua contemporaneidade tornam $A$ corda um tanto presa à época em que foi escrita (ABRANTES, 2004); entretanto, a peça discute questões ainda pertinentes da sociedade angolana, como os problemas do racismo e da corrupção (CZART, 2010). O fato é que, por meio do jogo do cabo de guerra, Pepetela cria um claro protesto contra a guerra civil do pós-independência e faz um apelo aos angolanos para se unirem. Dessa forma, numa perspectiva didática, o jogo do cabo de guerra ensina o grupo de combatentes a ultrapassar o plano da competição física e alcançar o da reflexão crítica e da ação transformadora, tendo a peça desfecho favorável aos revolucionários.

Já em A revolta da casa dos ídolos, Pepetela constrói uma parábola para novamente provocar a reflexão crítica acerca dos problemas sociais e políticos de Angola do pós-1975, pois a peça trata de fato das relações conflituosas entre dominadores e dominados, da tradição versus renovação e, como em $A$ corda, da luta pelo poder. No primeiro ato, ainda com o pano corrido, dois apresentadores, $1^{\circ}$ e $2^{\circ}$, entram em cena e se dirigem diretamente ao público: “Talvez nem tudo nesta peça corresponda à verdade histórica” (PEPETELA, 1980, p. 13), diz o $1^{\circ}$ apresentador, que, um pouco mais adiante, conclui: "O que interessa, e isso é verdade, é que por aquela altura mais uma vez o Povo se revoltou e abalou o poder, naquilo que um historiador com imaginação chamou (aponta para o pano que começa a subir): A revolta da casa dos ídolos" (PEPETELA, 1980, p. 14). Lembramos que a primeira rubrica da peça indica que, tendo o pano corrido, "sobressai um letreiro que diz: 'Reino do Kongo, 1514”' (PEPETELA, 1980, p. 13), o que de imediato indica ser o palco um espaço propício para a narração, numa perspectiva brechtiana de teatro.

Em cena vemos o ferreiro Nimi, que, assumindo a função de griot, narra ao seu sobrinho Nanga como o reino do Kongo foi usurpado por Mbemba Nzinga, filho do rei Nzinga-a-Nkuvu. Influenciado pelos portu- 
gueses recém-chegados ao país, o rei Nzinga-a-Nkuvu renega os costumes africanos e adota os dos europeus, mudando até o próprio nome, passando, então, a se chamar D. João I; o mesmo ocorre com o seu filho mais velho, que também muda o seu nome Mbemba Nzinga para D. Afonso e impõe a religião católica como única na província que governa (Nsundi), mandando queimar aqueles que professam os rituais africanos. Com a morte do rei Nzinga-a-Nkuvu (D. João I), quem deveria assumir o reino seria o seu sobrinho Mpanzu-a-Nzinga, escolhido pelo Colégio de Eleitores, como reza a tradição; no entanto, o primogênito, com total apoio bélico dos portugueses, reivindica o trono, e, quando morre Mpanu-a-Nzinga na guerra pelo poder, Mbemba Nzinga (D. Afonso) toma o poder. A ação temporal da peça - ou seja, quando Nimi conta a história a Nanga - decorre após sete anos de governo de Mbemba Nzinga, que continua a recusar a tradição, mantendo-se do lado dos portugueses e fazendo vista grossa para a captura de escravos. Nesse contexto, dois grupos querem depor o rei usurpador: os populares, cujas principais personagens são Nimi, seu sobrinho Nanga e Masala - este último, embora seja sobrinho de um mani, discorda da cobrança de impostos e da escravatura, opondo-se frontalmente ao seu tio Mani-Soyo que, como castigo, vende-o como escravo aos portugueses, mas Masala foge e se une ao povo; e os aristocratas (governadores de províncias chamados manis) Mani-Vunda e Jorge Muxuebata, que querem conservar os costumes como, por exemplo, a cobrança de altos impostos que os mantêm no poder. Há ainda o grupo de portugueses - Capitão, Padre e Lopes - que estão do lado do rei do Kongo, apenas interessados em preservar a exploração do comércio de escravos e de marfim.

Perante a situação de opressão que vive o povo - regido por um rei que obedece às leis e à religião dos portugueses, permitindo o tráfico de escravos -, Nimi defende a tradição religiosa do Kongo, simbolizada pelo uso dos amuletos; por outro lado, Nanga e seu amigo Masala promovem a conscientização política dos populares e mostram que a apreensão dos amuletos a mando dos padres é, na realidade, um estratagema dos portugueses para desviar a atenção do povo do tráfico de escravos - como não conseguem mais capturar negros fora do território do Kongo, os portugueses passam a transformar em escravos os cidadãos do próprio Kongo. Quando finalmente conseguem conscientizar o povo, Nanga e Massala tentam iniciar uma revolta popular, mas são impedidos pelos manis. Mani-Vunda e Muxuebata têm interesse no trono do Kongo e abominam a ideia de o povo chegar ao poder. Por isso, eles mandam matar Nanga e se encarregam de devolver Masala a Mani-Soyo. Sem Nanga e sem Masala, os populares se veem sem forças e a revolta popular fracassa.

Como em $A$ corda, aqui também são narradas as articulações dos dominadores que têm como objetivo a manutenção e/ou aumento de suas posses, meta não apenas dos portugueses, mas também dos manis: "De que vive um mani? [...] De onde vem essa fortuna toda? Dos tributos que recebe das aldeias que governa, tributos que ele obriga a pagar segundo a sua 
força e o seu apetite" (PEPETELA, 1980, p. 122), diz Masala. Em relação à oposição entre tradição - representada principalmente pelo velho ferreiro Nimi e por Mani-Vunda - e renovação, encabeçada por Masala e Nanga, a peça mostra, como bem sintetiza Antonio Hildebrando, que a "tradição torna-se, na mão dos poderosos, elemento de manutenção de uma ordem injusta e mantenedora de privilégios, enfim um entrave para a transformação desejada" (HILDEBRANDO, 2009, p. 257-258). Desse modo, A revolta da casa dos ídolos ao fim e ao cabo aponta para a necessidade de uma renovação, mas uma renovação desejada pelo povo, como queria Nanga. Por isso a peça termina com a fala de Kuntuala, personagem que até então fora apenas citada, não havia efetivamente aparecido em cena, e cujo nome significa futuro: "No fundo, lá no fundo, vejo uma luz [...]. É a luz de Nanga! [...]. Sim, a luz de Nanga brilhará como um Sol por esta terra toda. Sinto. Sei. Muito longe, dentro de mim, mas dentro de mim, Kuntuala, o futuro" (PEPETELA, 1980, p. 157).

Seja pelo elenco de personagens cujos nomes, ações e atitudes são semelhantes às de personalidades políticas reais de Angola do período pós-independência em $A$ corda seja pela apropriação de um fato histórico ocorrido no antigo Kongo, ambientado no século XVI quando da chegada dos primeiros portugueses, em A revolta da casa dos ídolos, Pepetela se vale de uma construção dramatúrgica que pretende instigar a reflexão acerca do momento político de seu país e para isso utiliza recursos cênicos que fazem distanciar o seu receptor (leitor / espectador) dos acontecimentos narrados a fim de nele suscitar o senso crítico. É nesse sentido que a dramaturgia de Pepetela apresenta o principal objetivo do teatro épico brechtiano, que, em síntese, pretende "possibilitar ao espectador uma crítica fecunda, dentro de uma perspectiva social" (BRECHT, 2005, p. 97), e o autor angolano consegue converter o sentido didático, e mesmo escolar, trabalhado em $A$ corda numa proposta de conscientização efetivamente aprofundada da realidade social em A revolta da casa dos ídolos.

\section{DO SENTIDO DIDÁTICO AO CARÁTER ÉPICO-BRECHTIANO}

Uma educação política que pratique a educação estética e uma educação estética que leve a sério a formação política terão de esforçar-se para alcançar uma consciência capaz de superar a diferença entre a esfera do estético e a do político no seu conceito de cultura (KOUDELA, 1992, p. 19).

Na concepção de Brecht (2005, p. 47), o teatro deve empenhar-se em ensinar ao espectador "um determinado comportamento prático com vista à modificação do mundo, deve suscitar nele [público] uma atitude fundamentalmente diferente daquela a que está habituado"; é notório, pois, o caráter didático desse teatro que não pretende limitar-se a apresentar relações intersubjetivas - como, por exemplo, o teatro burguês, ao qual Brecht se opunha - mas sim tratar das determinantes sociais dessas relações (ROSENFELD, 2006). 
As peças didáticas escritas por Brecht na dita primeira fase de seu percurso dramatúrgico inserem-se numa tendência de uso do teatro para fins didáticos que havia se tornado frequente nas escolas alemãs a partir dos anos de 19207; como observa Bornheim (1996, p. 184), "essa didática visava antes de tudo ao desenvolvimento da personalidade de jovens, e apresentava amiúde uma coloração de esquerda, revolucionária e até mesmo partidária”. Exemplo disso é a peça didática de Brecht $A$ decisão, que inclui no seu entrecho um coral intitulado "Elogio do partido".

Como o objetivo das peças didáticas detém-se na instrução, as cenas de julgamento são recorrentes nesse teatro; afinal, nada melhor que o ato de julgar para provocar o pensamento: a decisão requer reflexão e suscita o debate - as peças Aquele que diz sim e Aquele que diz não de Brecht são exemplares. É nesse sentido que podemos caracterizar as peças didáticas como peças escolares, ou seja, destinadas à formação do indivíduo e às vezes escritas mesmo "para meninos e meninas" levarem-na à cena, como na proposta de encenação de $O$ voo sobre o oceano, de Brecht, permitindo a ideia de supressão do público:

Há uma máxima que orienta o teatro didático: fazer é melhor do que sentir. A rigorosa consequência disso é que o público seja suprimido, todos devem atuar e participar ativamente da montagem [...]. Mas o principal está sempre na transmissão de uma ideia, que deve ficar clara para todos. (BORNHEIM, 1996, p. 184-185).

É por esta razão que Brecht propõe que as peças didáticas incorporem o público no processo teatral, "permitindo-lhe penetrar nas ações que se desenrolam no palco em que ele [público] por fim quase se desvanece como espectador" (KOUDELA, 1992, p. 42).

Do que foi dito até aqui acerca das peças didáticas, dá-se a impressão de um teatro apenas utilitário, desprovido da dimensão estética e artística ou da função de divertimento, o que nem sempre é verdade. Nas palavras do próprio Brecht (2005, p. 69), "o teatro não deixa de ser teatro, mesmo quando é didático; e desde que seja bom teatro, diverte”. Além disso, é preciso lembrar que é "através da teoria e prática da peça didática, [que] Brecht cria um método de exame da realidade social” (KOUDELA, 1992 , p. 33) e concebe, a partir daí, a sua proposta de teatro épico como renovador da estética teatral cênica e dramatúrgica do século XX.

De acordo com os pressupostos brechtianos, o teatro épico, no lugar de suscitar a identificação do público com a cena apresentada no palco, deverá, ao contrário, provocar no espectador o distanciamento dos acontecimentos narrados; é esse efeito de distanciamento (Verfremdungseffekt) que possibilita a reflexão crítica e, por conseguinte, a conscientização da transformação social, o que não deixa de ser também um ensinamento. Brecht avança do teatro didático para o teatro épico - o famoso esquema em que difere a "Forma dramática do teatro" da "Forma épica do teatro" 
foi precisamente elaborado no período em que o dramaturgo alemão ocupava-se do teatro didático (BORNHEIM, 1996). Nesse processo, podemos dizer que o dramaturgo alemão transforma criativamente o caráter didático de simples técnica para educar num pressuposto estético definidor de um novo teatro, que, entretanto, preserva em seu bojo a dimensão pedagógica, pois "no conceito de distanciamento está inserido o caráter pedagógico - afinal provoca-se o afastamento do espectador justamente para que ele apreenda a realidade e aprenda com ela" (RODRIGUES, 2010, p. 57). Assim, ao encerrar o ciclo do teatro didático, Brecht concentra-se nas teorias do teatro épico; no entanto, suas peças continuam conscientemente pedagógicas (BORNHEIM, 1996).

$\mathrm{Na}$ estrutura de ambas as peças que aqui constituem o nosso objeto de reflexão, há o intento didático com o qual Pepetela, apropriando-se tanto da lição de Brecht como da tradição oral dos griots, pretende "acordar" o seu público leitor / espectador. Assim, repetidas vezes, Likishi, o juiz de combate de $A$ corda, dirige-se diretamente ao público, convidando-o a pensar:

Abram os olhos, abram os ouvidos, deixem de respirar. A vossa vida está em jogo, a nossa vida depende desse combate. Quem irá ganhar? (Barulho forte de ngoma). Esperem um pouco, tremam, mas sobretudo, e isso é o mais importante, não deixem de pensar. Que nem um segundo a vossa cabeça pare de pensar. Para isso estou aqui (PEPETELA, 1980, p. 8).

Ao mesmo tempo em que Likishi está vinculado aos rituais africanos, caracteriza-se como uma personagem épica-brechtiana por excelência, que conduz o jogo e procura insistentemente despertar a plateia para a reflexão. Na cena X, Likishi, que até então não havia procurado esconder o seu posicionamento frente ao combate que ali se trava, solicita a opinião do público: "Mas dum lado há a pureza, embora com erros e defeitos. Do outro, só há a ganância, a vigarice. Eu, como Povo, devo ficar indiferente? Respondam, ajudem-me, devo ou não intervir?" (PEPETELA, 1980, p. 41); quem responde é um ator que, segundo a rubrica, encontra-se entre os espectadores da peça. O que estava sendo pedido ao público - pensar - passa a ser solicitado aos combatentes, isto é, ao Povo Angolano do palco: "Pensem, meus filhos, e vencerão". Ao voltar-se diretamente ao público, Likishi muda a máscara de juiz para a de povo, assumindo um posicionamento claro do lado dos combatentes, numa busca pela cumplicidade e participação do espectador ${ }^{8}$.

A corda transmite de forma bastante simples e direta o ensinamento de que "Ganha-se com a cabeça", por isso Likishi ostensivamente incita o público a pensar; o mesmo ocorre na segunda peça de Pepetela, em que Masala repete insistentemente ao povo do Kongo: "Parem com choradeiras e vamos pensar [...] Não há que chorar. Há que pensar. [...] Temos de pensar como acabar com as nossas desgraças” (PEPETELA, 1980, p. 101-102). 
O caráter didático de $A$ revolta da casa dos ídolos se instaura inicialmente na narrativa de Nimi, quando ele conta a história recente do Kongo ao jovem Nanga, que passa a elaborar um julgamento crítico a respeito das relações de poder e os problemas que essas relações causam ao país como um todo; com isso, a peça pretende alegoricamente despertar no espectador a reflexão acerca das questões políticas de Angola do período pós-independência. A estruturação do ambiente em determinadas cenas dessa peça cumpre a função didática de mostrar ou demonstrar o que se quer ensinar e constitui um recurso épico-brechtiano fundamental utilizado por Pepetela. Por exemplo, a narrativa de Nimi em dado momento dá lugar à encenação teatral, e o espectador vê no palco o teatro dentro do teatro: "(Ilumina-se o lado esquerdo. O Rei está sentado numa cadeira, rodeado de dois nobres. Entram o capitão português e padres e soldados, que lhe oferecem presentes. Vão mimando a acção que é descrita por Nimi, do lado direito)" (PEPETELA, 1980, p. 18). São cenas paralelas teatralizadas que mostram o conteúdo da fala de Nimi, personagem que, em consonância com a tradição dos griots, é quem narra a chegada dos primeiros portugueses:

Chegaram então brancos em navios de Mpinda. Trouxeram presentes para o Rei. Voltaram para as suas terras com presentes. Tempos depois, outros vieram. E chegaram até aqui. Os presentes eram uns pedreiros para fazerem um palácio para o Rei, e uma igreja. E padres. E outros presentes. Uns partiram, os padres ficaram [...]. (PEPETELA, 1980, p. 18).

A fala de Nimi e a cena que se desenvolve ali ao lado dessa personagem apresentam o contexto histórico e político da peça com a finalidade de instruir o público. Vemos, então, que o palco torna-se efetivamente propício à narração e ao despertar da consciência, caracterizando a cena épica brechtiana. Assim sendo, o público é "avisado" o tempo todo de que está no teatro, que o que se desenvolve no palco é uma representação que tem como objetivo fazer o espectador pensar sobre a cena mostrada e não simples e puramente fazê-lo identificar-se com ela.

Outra cena de cariz épico dessa peça ocorre no fim do primeiro ato, quando Nanga, sozinho no palco, "fala para fora", ou seja, para o público:

Infelizmente nasci um homem normal. Para sofrer e me revoltar, vendo o que fazem aos meus irmãos. [...] Um homem que foge à sua consciência não é um homem, é uma lagarta. E eu prefiro ver e ouvir mesmo se sofro, para ganhar forças para pensar. [...] São os desgraçados arrancados de suas sombras, das suas lavras, que me vão ensinar. Eles sabem, Kuntuala, eles sabem! (PEPETELA, 1980, p. 59-60).

Pepetela vale-se da composição visual nesta cena, pois a rubrica indica que, surgindo do lado direito, uma fila de homens e mulheres acorrentados percorrerá lentamente o palco enquanto durar essa fala de Nanga (excerto citado acima). Esse conjunto cênico forma um todo complexo: a aparição dos seres acorrentados paulatinamente projeta em imagem a fala 
de Nanga, é essa "projeção" que faz a cena saltar do sentido meramente didático para a caracterização épica, pois, sem chegar a suplantar a fala de Nanga, a imagem se impõe, provocando no espectador o olhar épico da distância (ROSENFELD, 2006), tornando, como propõe Brecht, "efetivamente possível um prazer artístico fundado no princípio do distanciamento" (BRECHT, 1967, p. 140).

A dramaturgia de Pepetela narra situações que ativam o juízo crítico do espectador. São elas vivenciadas por personagens que, ao longo da peça, também vão refletindo, aprendendo, como acontece com os combatentes de A corda ou com Nanga, de A revolta da casa dos ídolos: "A realidade força-me a pensar e a aprender", diz o jovem (PEPETELA, 1980, p. 59-60). O que transparece nas peças é a urgência de tornar o público consciente da condição político-social do país para que em solidária união possa concretizar a real transformação da sociedade. Por esta razão se faz tão presente o intento didático na dramaturgia do autor.

Aproveitando as considerações que Inocência da Mata (2003, p. 61) faz sobre a obra romanesca do autor angolano, podemos afirmar que também a literatura dramática de Pepetela por um lado (em $A$ revolta da casa dos ídolos) "contorna a distopia e antecipa outro 'desejo utópico', porque não se esgota num pretérito" e, por outro, reflete o percurso do encantamento, da utopia (em A corda); fazendo prevalecer nos dois casos o desejo e a esperança de um futuro melhor.

Assim como as questões políticas e os problemas sociais do período imediatamente após a independência de Angola integram o contexto da obra teatral de Pepetela, o sentido didático constitui a característica definidora da sua dramaturgia; parafraseando Brecht, não é porque essas peças de Pepetela abrangem a dimensão pedagógica do teatro que deixam de ser boa dramaturgia ou, como dizia o autor alemão, bom teatro - mas isso somente o palco confirmaria.

\section{REFERÊNCIAS BIBLIOGRÁFICAS}

ABRANTES, José Mena. O teatro em Angola. Luanda: Nzila, 2004.

BORNHEIM, Gerd. Brecht: a estética do teatro. Rio de Janeiro: Graal, 1992.

BRECHT, Bertolt. Teatro dialético: ensaios. Seleção e Introdução de Luiz Carlos Maciel. Rio de Janeiro: Civilização Brasileira, 1967.

Estudos sobre teatro. Trad. Fiama Pais Brandão. Rio de Janeiro: Nova Fronteira, 2005.

CHAVES, Rita; MACÊDO, Tânia (orgs.). Portanto... Pepetela. São Paulo: Ateliê Editorial, 2009.

CZART, Malgorzata. Consciência nacional angolana na obra teatral de Pepetela. Atas do X Congresso Luso-Afro-Brasileiro de Ciências Sociais: 
Sociedades desiguais e paradigmas em confronto - Lusofonia e (Neo)colonialismo: culturas e valores, identidades lingüísticas e estudos pós-coloniais, Minho, v. 1, p. 431-435, 2010.

HILDEBRANDO, Antonio. A revolta da casa dos ídolos: renovação e tradição. In: CHAVES, Rita; MACÊDO, Tânia. Portanto... Pepetela. São Paulo: Ateliê Editorial, 2009, p. 255-259.

KOUDELA, Ingrid Dormien. Um voo brechtiano. São Paulo: Perspectiva, 1992.

MATA, Inocência da. A condição pós-colonial das literaturas africanas de língua portuguesa: algumas diferenças e convergências e muitos lugares-comuns. In: LEÃO, Angela Vaz (org.). Contatos e ressonâncias: literaturas africanas de língua portuguesa. Belo Horizonte: Editora PUC-Minas, 2003, p. 43-72.

PEPETELA. A corda. Luanda: União dos Escritores Angolanos, série Lavra \& Oficina, 1980.

A revolta da casa dos ídolos. Lisboa: Edições 70, 1980.

RODRIGUES, Márcia Regina. Traços épico-brechtianos na dramaturgia portuguesa: O render dos heróis, de Cardoso Pires, e Felizmente há luar!, de Sttau Monteiro. São Paulo: Cultura Acadêmica, 2010.

ROSENFELD, Anatol. O teatro épico. São Paulo: Perspectiva, 2006.

VALENTIM, Jorge Vicente. Com quantos nós se faz uma trama: ressonâncias do teatro do oprimido em A corda, de Pepetela. Via Atlântica. São Paulo, no 22, p. 71-85, dez. 2012. Disponível em: http://www.revistas. usp.br/viaatlantica/article/view/51682 . Acesso em 12/04/2016.

Recebido para publicação em 31/05/2016 Aprovado em 11/11/2016

\section{NOTAS}

1 Márcia Regina Rodrigues é doutora em Estudos Literários; atualmente, realiza pesquisa de Pós-Doutorado - "As contribuições de Luís de Lima para o teatro brasileiro e português (1953-1974)" - no Departamento de Literatura da FCL-UNESP/Araraquara.

2 A corda foi traduzida para o russo e publicada em Moscou em 1983; A revolta da casa dos ídolos foi traduzida para o italiano e publicada em Roma em 1988 (CHAVES \& MACÊDO, 2009).

3 Verfremdungseffekt é o termo que designa o princípio básico da dramaturgia brechtiana e constitui o principal recurso épico proposto por Brecht; foi traduzido para o português como "distanciamento", "efeito de distanciação", "estranhamento", "efeito-V" e até "alienação" (termo advindo de algumas traduções francesas).

4 Em 1958, Pepetela vai para Lisboa estudar Engenharia, mas acaba por mudar para o curso de História; em 1962, a fim de se livrar da convocação do exército, parte para Paris (CHAVES \& MACÊDO, 2009) 
5 Felizmente, há luar!, de Sttau Monteiro, trata da trajetória do General Gomes Freire de Andrade, líder da conspiração liberal, sentenciado à morte, em 1817, pelos governadores do reino. O render dos heróis, de Cardoso Pires, trata da conhecida revolta popular denominada "Maria da Fonte", ocorrida em 1846.

6 De acordo com Czart, "likishi é um nome geral, fortemente ligado com os rituais africanos, que significa simplesmente um bailarino tradicional tchokuê, em outras regiões conhecido como xinganji [...] likishi tem um papel importante nos ritos de iniciação dos jovens, já que a sua missão é ensinar aos jovens os adequados códigos de conducta na vida adulta, ou seja, criar simbolicamente os homens adultos, os novos membros da comunidade étnica" (CZART, 2010, p. 433).

7 Segundo Bornheim, “o sucesso de Brecht com as peças didáticas, sobretudo em colégios, era muito grande, o que o encorajava a continuar explorando o rico filão" (BORNHEIM, 1996, p. 187-188).

8 É por essa razão que Jorge Valentim (2012) vê nesta personagem a caracterização do Coringa do teatro do oprimido concebido por Augusto Boal. 